\title{
Quality Characteristics of Chicken Emulsion Sausages with Different Levels of Makgeolli Lees Fiber
}

\author{
Kwoan-Sik Park, Yun-Sang Choi ${ }^{1}$, Hack-Youn Kim, Hyun-Wook Kim, Dong-Heon Song, \\ Ko-Eun Hwang, Seul-Gi Choi, and Cheon-Jei Kim* \\ Department of Food Science and Biotechnology of Animal Resources, Konkuk University, Seoul 143-701, Korea \\ ${ }^{1}$ Food and Biological Resources Examination Division, Korean Intellectual Property Office, Daejeon 302-701, Korea
}

\begin{abstract}
s
Makgeolli lees is a by-product of the makgeolli brew processing. Makgeolli lees contains high levels of fibers, which can be separated and used to develop foods rich in dietary fibers. The purpose of this study was to determine the effect of makgeolli fibers $(0-4 \%)$ on proximate composition, caloric content, $\mathrm{pH}$, color, cooking yield, textural profile, and sensory characteristics of chicken-emulsion sausages. The moisture content of 1, 2, and 3\% makgeolli lees fiber-amended product was higher than the control, while that of the $4 \%$ product was not. Total calorie estimates of makgeolli lees fiber-amended sausages were lower than the control, except for in the case of the $4 \%$ treatment. Moreover, chicken sausages supplemented with makgeolli lees fiber had higher cooking yields and improved textural properties. Chicken emulsion sausages prepared with makgeolli lees fiber had improved overall acceptability, and the best results of sensory characteristics were obtained for the emulsion sausages containing $2 \%$ makgeolli lees fiber.
\end{abstract}

Key words: makgeolli lees, dietary fiber, chicken, emulsion sausage, sensory characteristics

\section{Introduction}

Chicken meat and products have grown in popularity due to their nutritional characteristics, while also providing an excellent source of animal protein for consumers in developing countries (Deumier and Collignan, 2003). Chicken meat provides high protein and low fat, and chicken lipids are characterized by relatively high levels of unsaturated fatty acids, which are considered to be positive and healthy by consumers (Bonoli et al., 2007; Hwang et al., 2011). In particular, chicken emulsion sausage is a popular chicken meat-based product. Chicken meat processors are responding to the marketplace demand by producing reduced fat chicken meat products (Hwang et al., 2011). The production and consumption of chicken sausages has been increasing globally. These sausages are becoming more popular due to their sensory characteristics and ease of preparation, which reflects the development of more functionality-enhanced chicken

\footnotetext{
*Corresponding author: Cheon-Jei Kim, Department of Food Science and Biotechnology of Animal Resources, Konkuk University, Seoul 143-701, Korea. Tel: 82-2-450-3684, Fax: 82-2444-6695, E-mail: kimcj@konkuk.ac.kr
}

emulsion sausages with added dietary fiber.

Traditional Korean rice wine (makgeolli) is one of the most popular alcoholic beverages in Korea (Bae et al., 2010). Korean rice wine is brewed by conventional methods using nuruk or koji and is comprised of water, yeast, and rice that have been fermented for about 16 days without distillation (Jeong et al., 2006; Kim et al., 1995; Park and Lee, 2002). Makgeolli contains polyphenols, polysaccharides, and polysaccharide-peptide complexes (Blandino et al., 2003; Jeong and Park, 2006; Lee et al., 1996; Lee et al., 2009), and assorted bioactive components have been evaluated for their positive effects on health.

Makgeolli lees (also known as juback or sulchigegie) is a by-product of makgeolli brew processing. Commonly used as animal feeds or fertilizers (Won et al., 2006). Makgeolli lees is produced in large amounts annually in Korea, and it provides energy, dietary fiber, proteins, minerals, vitamins, alcohol, and organic acids required for human health (Jeong and Park, 2006; Park and Lee, 2002). Makgeolli lees is highly nutritious, lowers blood cholesterol, decreases the incidence of atherosclerosis, and has a laxative effect (Kim and Cho, 2006). Makgeolli powder has been studied for use in functional foods (Jeong and Park, 2006). However, no studies have yet 
been reported on the makgeolli lees extracted from makgeolli fiber, and its incorporation into chicken meat emulsion sausage. Dietary fiber has been studied alone or combined with other ingredients to prepare meat product formulations. The technological effect on foods differs according to the quantity and nature of the dietary fiber. Thus, makgeolli lees fiber is not only desired for its nutritional properties, but also for its functional and technological properties (Cho and Lee, 1996). Therefore, the objective of this study was to evaluate and compare the compositional, nutritional, and sensory properties of chicken emulsion sausages produced with different concentrations of makgeolli lees fiber.

\section{Materials and Methods}

\section{Preparation and processing of makgeolli lees fiber extract}

Dietary fiber was extracted using the modified AOAC enzymatic-gravimetric method (2007). Makgeolli lees was obtained from the Seoul Takju Map Association (Korea). Alcoholic components were removed by washing three times with four volumes of water $\left(25^{\circ} \mathrm{C}\right)$, and the residue was dried $\left(55^{\circ} \mathrm{C}\right)$ overnight in an air oven and then cooled. The makgeolli lees was gelatinized with $0.6 \%$ termamyl (heat stable alpha-amylase) at $95^{\circ} \mathrm{C}$ for $1 \mathrm{~h}$ to remove starch, followed by filtration. The residue was then washed three times with four volumes of heated water $\left(100^{\circ} \mathrm{C}\right)$ and allowed to equilibrate to room temperature $\left(20^{\circ} \mathrm{C}, 6 \mathrm{~h}\right)$. The residue was then washed with $99.9 \%$ ethanol (preheated to $60^{\circ} \mathrm{C}$ ) and filtered. The residue was dried $\left(55^{\circ} \mathrm{C}\right)$ overnight in an air oven and cooled. The makgeolli lees fiber (moisture content: $3.42 \pm 0.14 \%$; fat content: $5.98 \pm 0.28 \%$; protein content: $15.51 \pm 0.78 \%$; ash content: $0.60 \pm 0.06 \%$; dietary fiber content: $60.39 \pm$ $3.81 \%$; CIE L ${ }^{*}$-value: $67.35 \pm 1.02$; CIE a ${ }^{*}$-value: $4.62 \pm 0.45$; CIE $b^{*}$-value: $16.09 \pm 0.85$; pH: $\left.4.76 \pm 0.24\right)$ was then placed in polyethylene bags and vacuum packaged using a model FJ-500XL vacuum packaging system (Fujee Tech, Korea) and stored at $4^{\circ} \mathrm{C}$ until used for product manufacture (Choi et al., 2010a).

\section{Chicken meat batter preparation and processing}

Fresh chicken breast meat (broilers, Muscularis pectoralis major, $5 \mathrm{wk}$ of age, approximately $1.5-2.0 \mathrm{~kg}$ live weight, moisture content: $74.95 \pm 0.97 \%$, protein content: $22.58 \pm 0.43 \%$, fat content: $1.09 \pm 0.12 \%$, ash content: 1.31 $\pm 0.09 \%$ ) and pork back fat (moisture content: $12.73 \pm 0.14 \%$, fat content: $85.73 \pm 1.34 \%$ ) were purchased from a local processor. Chicken breast meat and pork back fat were initially ground through an $8-\mathrm{mm}$ plate. The ground tissue was then placed in polyethylene bags, vacuum-packaged using the afrementioned vacuum packaging system, and stored at $-15^{\circ} \mathrm{C}$ until used for product manufacture. Suitable amounts of the muscle and fat were tempered at $4^{\circ} \mathrm{C}$ for $24 \mathrm{~h}$ prior to meat batter preparation. Each sample batch consisted of five meat batters differing in composition with respect to the addition of makgeolli lees fiber level $(0,1,2,3$, and $4 \%)$. All emulsion sausages were composed by $50 \%$ chicken breast meat, $30 \%$ pork back fat, and $20 \%$ ice. Raw meat was homogenized and ground for $1 \mathrm{~min}$ in a model Nr-963009 silent cutter (Hermann Scharfen, Germany), and $1.5 \%$ salt $(\mathrm{NaCl}), 0.15 \%$ sodium tripolyphosphate, $0.4 \%$ sorbitol, $0.08 \%$ monosodium Lglutamate, $0.07 \%$ onion powder, and $0.07 \%$ ginger powder were added to meat that had been previously dissolved in water, chilled $\left(2^{\circ} \mathrm{C}\right)$, and then mixed for $1 \mathrm{~min}$. Makgeolli lees fiber was added to the meat batter, which was homogenized for 6 min. A model KM330 temperature probe (Kane-May, Germany) was used to monitor the temperature of the emulsion, which was maintained below $10^{\circ} \mathrm{C}$ during batter preparation. After emulsification, the chicken meat batter was stuffed into collagen casings (\#240, NIPPI, Japan; approximate diameter of 25 $\mathrm{mm}$ ) using a model IS-8 stuffer (Sirman, Italy). The meat batter was then heated at $75 \pm 2^{\circ} \mathrm{C}$ for $30 \mathrm{~min}$ in a water bath (Dae Han Co, Model 10-101, Korea), and internal temperature of emulsion sausage is $75^{\circ} \mathrm{C}$. The cooked meat batter was then cooled with cold water. Ten kilogram batches of each chicken emulsion sausage were prepared in this manner. All analyses were carried out in triplicate for each formulation.

\section{Proximate composition}

Compositional properties of the chicken meat sausages were determined using AOAC guidelines (2007). Moisture content was determined by weight loss after $12 \mathrm{~h}$ of drying at $105^{\circ} \mathrm{C}$ in a model SW-90D drying oven (Sang Woo Scientific Co., Korea). Crude fat content was determined by the Soxhlet method using a Soxtec ${ }^{\circledR}$ Avanti2050 solvent auto-extraction system (Foss Tecator AB, Sweden), and crude protein was determined by the Kjeldahl method with a Kjeltec ${ }^{\circledR} 2300$ automatic Kjeldahl nitrogen analyzer (Foss Tecator). Crude ash was determined according to AOAC method 923.03.

\section{Caloric content}

Total calorie estimates (kcal) for the chicken meat 
emulsion sausages were calculated based on a 100 -g portion using Atwater values for fat $(9 \mathrm{kcal} / \mathrm{g})$, protein $(4.02$ $\mathrm{kcal} / \mathrm{g}$ ), and carbohydrate $(3.87 \mathrm{kcal} / \mathrm{g}$ ) (Mansour and Khalil, 1999).

\section{pH}

The $\mathrm{pH}$ values of the chicken sausages were measured in a homogenate prepared with $5 \mathrm{~g}$ of sample and distilled water $(20 \mathrm{~mL})$ using a model $340 \mathrm{pH}$ meter (MettlerToledo GmbH, Switzerland). All determinations were performed in triplicate.

\section{Color evaluation}

The color of each chicken emulsion sausage was determined using a colorimeter (Minolta Chroma meter CR210, Minolta, Japan; illuminate C, calibrated with a white plate, $\mathrm{CIE} \mathrm{L}^{*}=+97.83, \mathrm{CIE} \mathrm{a}^{*}=-0.43, \mathrm{CIE} \mathrm{b}^{*}=+1.98$ ). The emulsion sausages were sliced parallel to the flat surface in the center of samples. Six measurements for each of five replicates were measured on a cut surface taken. Lightness (CIE L ${ }^{*}$-value), redness (CIE a*-value), and yellowness (CIE $b^{*}$-value) values were recorded.

\section{Cooking yields}

Chicken emulsion sausages were weighed before heat processing and after chilling at $4^{\circ} \mathrm{C}$ for $24 \mathrm{~h}$. The cooking yield was determined from their weights and expressed as a percentage of initial weight (Lee et al., 2008).

Cooking yields (\%)

$=[$ emulsion sausage weight after cooking $(\mathrm{g})$ /emulsion sausage weight before cooking $(\mathrm{g})] \times 100$

\section{Texture profile analysis (TPA)}

Texture measurements in the form of a TPA were performed at room temperature with a TA-XT2i texture analyzer (Stable Micro Systems, UK). Chicken emulsion sausage samples were taken from the central portion of each sample. Prior to analyses, samples were allowed to equilibrate to room temperature $\left(20^{\circ} \mathrm{C}, 3 \mathrm{~h}\right)$. The conditions for the texture analysis were pre-test speed, $2.0 \mathrm{~mm} /$ $\mathrm{s}$; post-test speed, $5.0 \mathrm{~mm} / \mathrm{s}$; maximum load, $2 \mathrm{~kg}$; head speed, $2.0 \mathrm{~mm} / \mathrm{s}$; distance, $8.0 \mathrm{~mm}$; and force, $5 \mathrm{~g}$. TPA values were calculated using force and time plots. Values for hardness $(\mathrm{kg})$, springiness, cohesiveness, gumminess $(\mathrm{kg})$, and chewiness $(\mathrm{kg})$ were determined as described previously (Bourne, 1978).

\section{Sensory evaluation}

Each chicken emulsion sausage was evaluated for appearance color, flavor, juiciness, tenderness, and overall acceptability (Choi et al., 2008). Emulsion sausages were cooked with a center temperature of $75^{\circ} \mathrm{C}$, and the cooked samples were cooled to room temperature at $21^{\circ} \mathrm{C}$, cut into quarters, and served to panelists in random order. Each sample (height $\times$ diameter; $3.0 \times 2.5 \mathrm{~cm}$ ) was coded with randomly selected 3 -digit numbers. Sensory evaluations were performed by the panelists under fluorescent lighting. Panelists were instructed to cleanse their palates with water between samples. The color $(1=$ extremely undesirable, $10=$ extremely desirable), flavor (1=extremely undesirable, $10=$ extremely desirable), tenderness ( $1=$ extremely tough, $10=$ extremely tender), juiciness ( $1=$ extremely dry, $10=$ extremely juicy), and overall acceptability ( $1=$ extremely undesirable, $10=$ extremely desirable) of the cooked samples were evaluated using a 10-point descriptive scale. The panel consisted of 11 members from the Department of Food Sciences and Biotechnology of Animal Resources, Konkuk University.

\section{Statistical analysis}

An analysis of variance was performed on all the variables measured using the general linear model (GLM) procedure of the SAS statistical package (SAS, USA) (2008). Duncan's multiple range test $(p<0.05)$ was used to determine the differences between treatment means.

\section{Results and Discussion}

\section{Proximate composition and caloric content of chicken emulsion sausages}

Table 1 shows the proximate composition of the chicken emulsion sausages formulated with various makgeolli lees fiber levels. The moisture content of the chicken emulsion sausages samples containing makgeolli lees fiber were higher than that of the control sample $(p<0.05)$, except for the $4 \%$ makgeolli lees fiber sample. The latter result likely reflected the reduced water retention in the presence of excess dietary fiber (Choi et al., 2008). Choi et al. (2010a) reported similar quality characteristics of chicken emulsion plus dietary fiber extracted from takju lees. In another study, the moisture content increased with increasing rice wine residue in high fiber breads (Cho and Lee, 1996). These results agree with those reported by Choi et al. (2009), in which the moisture content increased in rice bran fiber added to meat emulsion systems. Also, Lee et al. (2008) indicated that kimchi fiber produces meat products with higher moisture content. Presently, no significant difference was observed for the 
Table 1. Proximate composition of cooked chicken emulsion sausage formulations with various concentrations of makgeolli lees fiber

\begin{tabular}{ccccc}
\hline \hline $\begin{array}{c}\text { Treat- } \\
\text { ments }^{1)}\end{array}$ & $\begin{array}{c}\text { Moisture } \\
(\%)\end{array}$ & $\begin{array}{c}\text { Protein } \\
(\%)\end{array}$ & $\begin{array}{c}\text { Fat } \\
(\%)\end{array}$ & $\begin{array}{c}\text { Ash } \\
(\%)\end{array}$ \\
\hline Control & $55.87 \pm 0.54^{\mathrm{b}}$ & $14.18 \pm 0.83$ & $27.40 \pm 0.88^{\mathrm{a}}$ & $2.28 \pm 0.02^{\mathrm{c}}$ \\
T1 & $57.18 \pm 0.48^{\mathrm{a}}$ & $14.11 \pm 1.01$ & $25.75 \pm 0.25^{\mathrm{b}}$ & $2.29 \pm 0.06^{\mathrm{c}}$ \\
T2 & $57.42 \pm 0.38^{\mathrm{a}}$ & $14.15 \pm 1.14$ & $25.12 \pm 0.62^{\mathrm{b}}$ & $2.32 \pm 0.03^{\mathrm{bc}}$ \\
T3 & $57.10 \pm 0.61^{\mathrm{a}}$ & $14.27 \pm 0.96$ & $26.04 \pm 0.53^{\mathrm{ab}}$ & $2.34 \pm 0.05^{\mathrm{b}}$ \\
T4 & $55.40 \pm 0.05^{\mathrm{b}}$ & $14.34 \pm 1.09$ & $27.11 \pm 0.78^{\mathrm{a}}$ & $2.38 \pm 0.07^{\mathrm{a}}$ \\
\hline
\end{tabular}

All values are mean \pm standard deviation of three replicates.

${ }^{\mathrm{a}-\mathrm{c}}$ Means within a column with different letters are significantly different $(p<0.05)$.

${ }^{1)}$ Control, chicken emulsion sausage without makgeolli lees fiber; T1, chicken emulsion sausage with $1 \%$ makgeolli lees fiber; T2, chicken emulsion sausage with $2 \%$ makgeolli lees fiber; T3, chicken emulsion sausage with $3 \%$ makgeolli lees fiber; T4, chicken emulsion sausage with $4 \%$ makgeolli lees fiber

protein content of the chicken emulsion sausages samples $(p>0.05)$. The fat content of the makgeolli lees fiber in the chicken emulsion sausages was the lowest in the $1 \%$ and $2 \%$-treated samples $(p<0.05)$. These results may be affected by increasing moisture content of emulsion sausages due to added makgeolli lees fiber. The fat and moisture contents are closely related in meat products. Garcia et al. (2002) reported that cereal and fruit fiber decreases the fat content of sausages, and the results differ significantly between the control and treatments. Choi et al. (2010b) indicated that the addition of rice bran fiber decreased the fat content of frankfurters significantly. The ash content of chicken emulsion sausages with makgeolli lees fiber was higher than that of control samples, and sausages treated with increasing amounts of makgeolli lees fiber were higher in ash content, as the ash content of makgeolli lees fiber is about $0.60 \%$. Similar results were reported by Choi et al. (2008) for meat products containing rice bran fiber. Chung (2009) reported on the influence of adding purple sweet potato powder on the quality characteristics of cookies, as increasing the purple sweet potato powder content increased the ash content of the cookies.

The total calorie estimates of the chicken emulsion sausages formulated with different levels of makgeolli lees fibers are shown in Fig. 1. The higher energy values occurred in the control $(308.01 \mathrm{kcal} / 100 \mathrm{~g})$ and treatments with $4 \%$ makgeolli lees fiber $(\mathrm{T} 4,303.84 \mathrm{kcal} / 100 \mathrm{~g})$ compared to the other treatments $(p<0.05)$. The energy values of the other chicken emulsion sausages ranged from 294.40 to $298.75 \mathrm{kcal} / 100 \mathrm{~g}$, whereas the $2 \%$ makgeolli lees fiber treatment $(\mathrm{T} 2,290.86 \mathrm{kcal} / 100 \mathrm{~g})$ had the

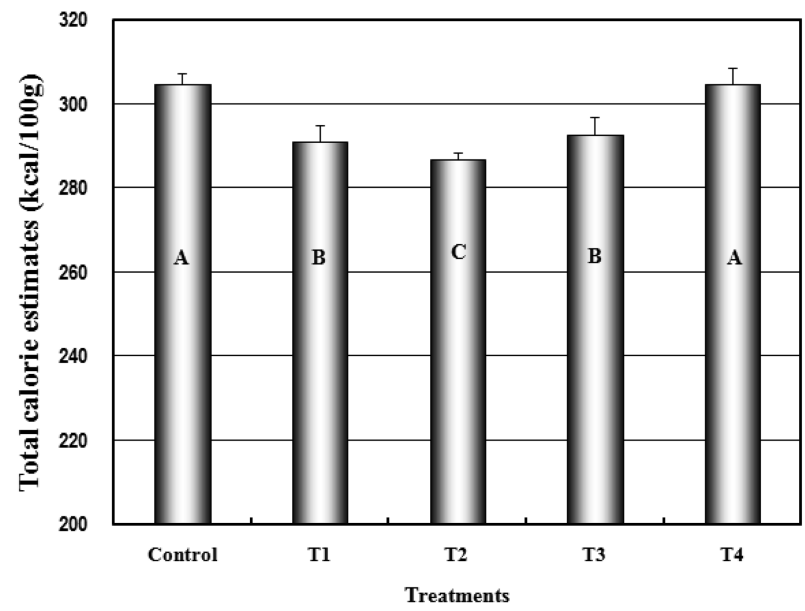

Fig. 1. Effects of makgeolli lees fiber on total calorie estimates of chicken emulsion sausages. ${ }^{\mathrm{A}-\mathrm{C}}$ Means in the treatments with different letters are significantly different $(p<0.05)$. Control, chicken emulsion sausage without makgeolli lees fiber; T1, chicken emulsion sausage with $1 \%$ makgeolli lees fiber; T2, chicken emulsion sausage with $2 \%$ makgeolli lees fiber; T3, chicken emulsion sausage with $3 \%$ makgeolli lees fiber; $\mathrm{T} 4$, chicken emulsion sausage with $4 \%$ makgeolli lees fiber

lowest energy values $(p<0.05)$, reflecting the fact that $2 \%$ makgeolli lees fiber provides higher water retention. Choi et al. (2010b) indicated lower energy and cholesterol contents of reduced-fat frankfurters with rice bran fiber used for fat reduction and as a fat replacer. Furthermore, Grigelmo-Miguel et al. (1999) reported that low-fat frankfurters supplemented with high dietary fiber provide lower energy values. These results are in agreement with the results obtained by Choi et al. (2008) that the energy vales of tteokgalbi with added rice bran fiber were significantly higher than those of control sausages. Similar results were reported by Cengiz and Gokoglu (2005) for sausages containing citrus fiber and by Turhan et al. (2005) for low-fat frankfurters with added hazelnut pellicle.

\section{Cooking yields of chicken emulsion sausages}

The data concerning cooking yields of the chicken emulsion sausages made with different makgeolli lees fibers levels are shown in Fig. 2. The treatments containing makgeolli lees fiber had higher cooking yields than the control $(p<0.05)$ and no significant differences among treatments containing makgeolli lees fiber $(p>0.05)$ were observed. Similar studies have reported that adding dietary fiber such as kimchi fiber, rice bran fiber, oat fiber, inner pea fiber, hazelnut pellicle fiber, lemon albedo fiber, tiger nut fiber, or carrot fiber increases cooking yields in meat products (Choi et al., 2009; Desmond et al., 1998; 


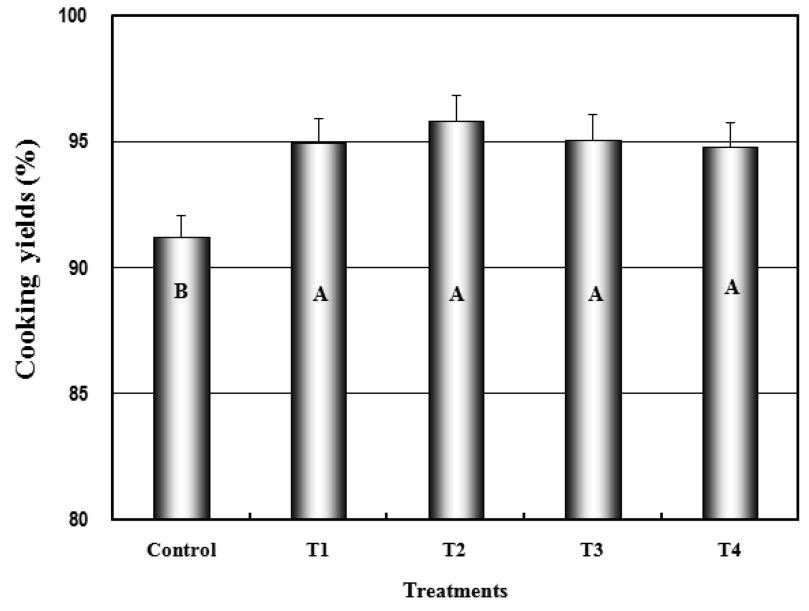

Fig. 2. Effects of makgeolli lees fiber on cooking yields of chicken emulsion sausages. ${ }^{\mathrm{A}, \mathrm{B}}$ Means in the treatments with different letters are significantly different $(p<0.05)$. Control, chicken emulsion sausage without makgeolli lees fiber; T1, chicken emulsion sausage with $1 \%$ makgeolli lees fiber; T2, chicken emulsion sausage with $2 \%$ makgeolli lees fiber; T3, chicken emulsion sausage with $3 \%$ makgeolli lees fiber; T4, chicken emulsion sausage with $4 \%$ makgeolli lees fiber

Eim et al., 2008; Fernández-Ginés et al., 2004; Lee et al., 2008; Turhan et al., 2005). Xiong et al. (1999) indicated that locust bean gum was particularly effective for increasing cooking yield in low-fat sausages, due to its ability to form hydrogen bonds with water. Adding dietary fiber to meat products significantly increases cooking yields by improving emulsion stability. Dietary fiber from different sources and prepared with different processing methods has been studied alone or combined with other ingredients in various meat products to improve cooking yields (Desmond et al., 1998; Lee et al., 2008). In general, water binds to dietary fiber through capillary action or by hydrogen bonds, ionic bonds, hydrophobic interactions, or by surface tension in the matrix pores (GrigelmoMiguel et al., 1999; Lee et al., 2008). Thus, dietary fiber extracted from makgeolli lees powder is potentially useful because it enhances these properties in meat products.

\section{pH and color of chicken emulsion sausages}

The $\mathrm{pH}$ values of the chicken emulsion sausages containing makgeolli lees fibers are provided in Table 2. Chicken emulsion sausages containing makgeolli lees fiber had a significantly lower $\mathrm{pH}$ than the control, and as increasing the level of makgeolli lees fiber lowered the $\mathrm{pH}(p<0.05)$. The findings that changes in makgeolli lees fiber levels significantly affected the $\mathrm{pH}$ of makgeolli lees fiber agree with a number of studies. Choi et al. (2010a) reported that $\mathrm{pH}$ was significantly decreased with the
Table 2. Effects of various makgeolli lees fiber on $\mathbf{p H}$ and color $\left(L^{*}-, a^{*}-\right.$, and $b^{*}$-values) of chicken emulsion sausages formulated with various concentrations of makgeolli lees fiber

\begin{tabular}{ccccc}
\hline \hline $\begin{array}{c}\text { Treat- } \\
\text { ments }\end{array}$ & $\mathrm{pH}$ & $\mathrm{L}^{*}$-value & $\mathrm{a}^{*}$-value & $\mathrm{b}^{*}$-value \\
\hline Control & $6.56 \pm 0.03^{\mathrm{a}}$ & $83.34 \pm 2.58^{\mathrm{a}}$ & $1.69 \pm 0.89^{\mathrm{a}}$ & $10.15 \pm 0.26^{\mathrm{c}}$ \\
$\mathrm{T} 1$ & $6.53 \pm 0.01^{\mathrm{b}}$ & $78.71 \pm 0.79^{\mathrm{b}}$ & $1.54 \pm 0.24^{\mathrm{b}}$ & $11.00 \pm 1.66^{\mathrm{b}}$ \\
$\mathrm{T} 2$ & $6.51 \pm 0.02^{\mathrm{bc}}$ & $78.28 \pm 2.02^{\mathrm{b}}$ & $1.31 \pm 0.57^{\mathrm{c}}$ & $11.01 \pm 1.22^{\mathrm{b}}$ \\
T3 & $6.49 \pm 0.02^{\text {cd }}$ & $76.80 \pm 1.68^{\mathrm{c}}$ & $1.24 \pm 0.37^{\mathrm{d}}$ & $11.32 \pm 1.50^{\mathrm{ab}}$ \\
T4 & $6.47 \pm 0.01^{\mathrm{d}}$ & $74.91 \pm 3.30^{\mathrm{d}}$ & $1.20 \pm 0.65^{\mathrm{d}}$ & $11.52 \pm 1.47^{\mathrm{a}}$ \\
\hline
\end{tabular}

All values are mean \pm standard deviation of three replicates

${ }^{\text {a-d }}$ Means within a column with different letters are significantly different $(p<0.05)$.

${ }^{1)}$ Control, chicken emulsion sausage without makgeolli lees fiber; $\mathrm{T} 1$, chicken emulsion sausage with $1 \%$ makgeolli lees fiber; $\mathrm{T} 2$, chicken emulsion sausage with $2 \%$ makgeolli lees fiber; T3, chicken emulsion sausage with $3 \%$ makgeolli lees fiber; T4, chicken emulsion sausage with $4 \%$ makgeolli lees fiber

addition of makgeolli lees fiber to meat emulsion systems. Jeong and Park (2006) indicated that the $\mathrm{pH}$ of bread containing takju powder decreases. Choi et al. (2008) observed significantly decreased $\mathrm{pH}$ with increasing levels of added rice bran fiber levels in chicken emulsion sausages. Eim et al. (2008) reported that adding carrot dietary fiber to sausages led to changes in $\mathrm{pH}$. The present and previous results conclusively demonstrate that the $\mathrm{pH}$ of meat products is altered by the presence of dietary fiber.

The color values of the chicken emulsion sausages were significantly affected by the makgeolli lees fiber powder concentration (Table 2). The control had significantly higher lightness and redness values than treatments containing makgeolli lees fiber $(p<0.05)$, and lightness and redness decreased with increasing makgeolli lees fiber content $(p<0.05)$. These significant reductions in lightness were due to the lower lightness of the makgeolli lees fiber. Choi et al. (2009) reported similar results, in which treatments groups had less lightness than the control due to added rice bran fiber. The yellowness values of chicken emulsion sausages with makgeolli lees fiber were higher than those of the control $(p<0.05)$, adding makgeolli lees fiber resulted in a significant increase in the yellowness value as the makgeolli lees fiber level increased $(p<0.05)$. The makgeolli lees fiber had lightness, redness, and yellowness values of $67.35,4.62$, and 16.09 , respectively, which would likely be the result of the rice, wheat, barley, and rice bran content. Jeong and Park (2006) reported that loaf bread with added takju powder did not significantly affect the lightness, redness, and yellowness val- 
Table 3. Effects of makgeolli lees fiber on the textural attributes of chicken emulsion sausages formulated with varying concentrations of makgeolli lees fiber

\begin{tabular}{|c|c|c|c|c|c|}
\hline Treatments $^{1)}$ & Hardness (kg) & Springiness & Cohesiveness & Gumminess (kg) & Chewiness (kg) \\
\hline Control & $1.93 \pm 0.23^{\mathrm{c}}$ & $0.90 \pm 0.06$ & $0.55 \pm 0.04^{b}$ & $1.22 \pm 0.21^{\mathrm{d}}$ & $1.21 \pm 0.18^{\mathrm{c}}$ \\
\hline $\mathrm{T} 1$ & $2.58 \pm 0.25^{\mathrm{bc}}$ & $0.97 \pm 0.02$ & $0.56 \pm 0.02^{b}$ & $1.44 \pm 0.28^{\mathrm{c}}$ & $1.35 \pm 0.27^{b c}$ \\
\hline $\mathrm{T} 2$ & $2.83 \pm 0.27^{\mathrm{b}}$ & $0.95 \pm 0.02$ & $0.56 \pm 0.05^{b}$ & $1.62 \pm 0.31^{\mathrm{b}}$ & $1.42 \pm 0.33^{b c}$ \\
\hline $\mathrm{T} 3$ & $2.92 \pm 0.28^{b}$ & $0.95 \pm 0.04$ & $0.57 \pm 0.02^{b}$ & $1.75 \pm 0.29^{b}$ & $1.53 \pm 0.25^{b}$ \\
\hline $\mathrm{T} 4$ & $3.42 \pm 0.19^{\mathrm{a}}$ & $0.95 \pm 0.03$ & $0.61 \pm 0.04^{\mathrm{a}}$ & $1.97 \pm 0.25^{\mathrm{a}}$ & $1.86 \pm 0.51^{\mathrm{a}}$ \\
\hline
\end{tabular}

All values are mean \pm standard deviation of three replicates.

${ }^{\text {a-d }}$ Means within a column with different letters are significantly different $(p<0.05)$.

${ }^{1)}$ Control, chicken emulsion sausage without makgeolli lees fiber; T1, chicken emulsion sausage with $1 \%$ makgeolli lees fiber; T2, chicken emulsion sausage with $2 \%$ makgeolli lees fiber; T3, chicken emulsion sausage with $3 \%$ makgeolli lees fiber; T4, chicken emulsion sausage with $4 \%$ makgeolli lees fiber

ues. The lightness, redness, and yellowness values of meat and meat products affect the color of the added sources of dietary fibers extracted from natural products (Choi et al., 2011; Choi et al., 2012; Eim et al., 2008; Grigelmo-Miguel et al., 1999; Lee et al., 2008).

\section{TPA of chicken emulsion sausages}

TPA data for the chicken emulsion sausages with different levels of makgeolli lees fiber are shown in Table 3. The hardness of samples with added makgeolli lees fiber was higher than that of the control and as the makgeolli lees fiber levels increased the hardness increased $(p<0.05)$. Normally, improving hardness of meat products results from the ability of dietary fiber to become a strongerbinding three-dimensional network (Choi et al., 2009; Choi et al., 2012; Lee et al., 2008). No significant differences in springiness were observed among the control and all of the treatments containing makgeolli lees fiber ( $p>0.05)$. Cohesiveness, gumminess, and chewiness were the highest for the $4 \%$ makgeolli lees fiber treatment sample $(p<0.05)$, and increased as makgeolli lees fiber levels increased. Similar increases in hardness, gumminess, and chewiness were obtained for meat products such as frank- furters, bologna, and ground patties due to added rice bran fiber, kimchi fiber, soy fiber, sea tangle fiber, chestnut peel fiber, and other types of fiber (Choi et al., 2009; Choi et al., 2010a; Colmenero et al., 2005; Lee et al., 2008; Steenblock et al., 2001; Thebaudin et al., 1997). In general, dietary fiber enhances the consistency of meat emulsion products by forming an insoluble three-dimensional network capable of modifying the rheological properties of meat emulsion systems (Lee et al., 2008). Thebaudin et al. (1997) reported that dietary fiber influences food texture due to its water binding ability and swelling properties.

\section{Sensory evaluation of the chicken emulsion sau- sages}

Table 4 shows the sensory property comparisons of the chicken emulsion sausages prepared with added makgeolli lees fiber. Adding makgeolli lees fiber decreased color scores, and all the treatments received lower scores than the control without makgeolli lees fiber $(p<0.05)$. This result was directly related to the makgeolli lees fiber levels added. Color has been a key problem in many studies examining additions of natural sources of dietary fiber

Table 4. Effects of makgeolli lees fiber on the sensory characteristics of chicken emulsion sausages formulated with varying concentrations of makgeolli lees fiber

\begin{tabular}{cccccc}
\hline \hline Treatments $^{1)}$ & Color & Flavor & Tenderness & Juiciness & Overall acceptability \\
\hline Control & $8.20 \pm 0.83^{\mathrm{a}}$ & $7.70 \pm 0.93$ & $7.30 \pm 0.35^{\mathrm{b}}$ & $7.20 \pm 0.46^{\mathrm{b}}$ & $7.50 \pm 0.46^{\mathrm{b}}$ \\
T1 & $8.10 \pm 0.93^{\mathrm{ab}}$ & $7.70 \pm 0.64$ & $7.60 \pm 0.46^{\mathrm{ab}}$ & $7.60 \pm 0.64^{\mathrm{ab}}$ & $7.50 \pm 0.71^{\mathrm{ab}}$ \\
T2 & $8.00 \pm 0.99^{\mathrm{ab}}$ & $7.80 \pm 0.71$ & $8.10 \pm 0.53^{\mathrm{a}}$ & $7.90 \pm 0.53^{\mathrm{a}}$ & $8.00 \pm 0.46^{\mathrm{a}}$ \\
T3 & $7.60 \pm 0.71^{\mathrm{ab}}$ & $7.90 \pm 0.64$ & $7.70 \pm 0.71^{\mathrm{ab}}$ & $7.75 \pm 0.74^{\mathrm{ab}}$ & $7.70 \pm 0.64^{\mathrm{ab}}$ \\
T4 & $7.50 \pm 0.53^{\mathrm{b}}$ & $7.80 \pm 0.53$ & $7.35 \pm 0.46^{\mathrm{b}}$ & $7.15 \pm 0.64^{\mathrm{b}}$ & $7.20 \pm 0.53^{\mathrm{b}}$ \\
\hline
\end{tabular}

All values are mean \pm standard deviation of three replicates.

${ }^{\mathrm{a}, \mathrm{b}}$ Means within a column with different letters are significantly different $(p<0.05)$.

${ }^{1)}$ Control, chicken emulsion sausage without makgeolli lees fiber; T1, chicken emulsion sausage with $1 \%$ makgeolli lees fiber; T2, chicken emulsion sausage with $2 \%$ makgeolli lees fiber; T3, chicken emulsion sausage with $3 \%$ makgeolli lees fiber; T4, chicken emulsion sausage with $4 \%$ makgeolli lees fiber. 
(Choi et al., 2010b; Choi et al., 2012; Lee et al., 2008). These results agree with those reported by Jeong and Park (2006), in which takju powder decreased the color scores of loaf breads, and increasing takju powder levels decreased color scores. Presently, the flavor scores of chicken emulsion sausages were not significantly different among the control and makgeolli lees fiber treatments $(p>0.05)$. Chicken emulsion sausages containing $2 \%$ makgeolli lees fiber received the highest scores for tenderness, juiciness, and overall acceptability $(p<0.05)$. Similar results were obtained for meat products with added rice bran fiber and hazelnut pellicle fiber with the same sensory properties (Choi et al., 2010a; Turhan et al., 2005). Furthermore, flavor and taste are affected by various additives such as lemon albedo, melon seed meal, acorn powder, and tiger nut fiber (Abiola et al., 2004; Chin and Ban, 2008; Fernández-Ginés et al., 2004; Sánchez-Zapata et al., 2010).

In conclusion, our results indicate that the makgeolli lees used in chicken emulsion sausages formulations significantly affects the proximate composition, caloric content, $\mathrm{pH}$, color, cooking yields, textural profile analysis, and sensory evaluation of the chicken emulsion sausages. Makgeolli lees shows potential as a good source of dietary fiber that can be used as a functional ingredient in chicken meat emulsion sausages. The chicken emulsion sausages with makgeolli lees fiber had improved physicochemical properties and sensory characteristics, and the best results were obtained for the chicken emulsion sausages with $2 \%$ of added makgeolli lees fiber.

\section{Acknowledgements}

This work was supported by Ministry for Food, Agriculture, Forestry and Fisheries funded by the Korean Government (608001-05-2-SB310). The authors also partially supported by the Brain Korean 21 (BK 21) Project from Ministry of Education and Human Resources Development.

\section{References}

1. Abiola, S. S., Kadiri, E. I., and Kareem, T. T. (2004) Effect of melon seed meal addition on some quality characteristics of chicken sausages. J. Sci. Food Argic. 84, 423-426.

2. AOAC. (2007) Official methods of analysis of AOAC. $18^{\text {th }}$ ed, Association of Official Analytical Chemists, Washington, DC.

3. Bae, S. H., Jung, E. Y., Kim, S. Y., Shin, K. S., and Suh, H. J. (2010) Antioxidant and immune-modulating activities of
Korean traditional rice wine, takju. J. Food Biochem. 34, 233-248.

4. Blandino, A., Al-Aseeri, M. E., Pandiella, S. S., Cantero, D., and Webb, C. (2003) Cereal-based fermented foods and beverages. Food Res. Int. 36, 527-543.

5. Bonoli, M., Caboni, M. F., Rodriguez-Estrada, M. T., and Lercker, G. (2007) Effect of feeding fat sources on the quality and composition of lipids of precooked ready-to-eat fried chicken patties. Food Chem. 101, 1327-1337.

6. Bourne, M. C. (1978) Texture profile analysis. Food Technol. 32, 62-66.

7. Cengiz, E. and Gokoglu, N. (2005) Changes in energy and cholesterol contents of frankfurter-type sausages with fat reduction and fat replacer addition. Food Chem. 91, 443-447.

8. Chin, K. B. and Ban, G. H. (2008) Evaluation of two levels and types of acorn powder on product quality of low-fat sausages as a fat replacer. J. Anim. Sci. Technol. 50, 217-226.

9. Cho, M. K. and Lee, W. J. (1996) Preparation high-fiber bread with soybean curd residue and makkolli (rice wine) residue. J. Korean Soc. Food Sci. Nutr. 25, 632-636.

10. Choi, Y. S., Choi, J. H., Han, D. J., Kim, H. Y., Kim, H. W., Lee, M. A., Chung, H. J., and Kim, C. J. (2012) Effects of Laminaria japonica on the physico-chemical and sensory characteristics of reduced-fat pork patties. Meat Sci. 91, 1-7.

11. Choi, Y. S., Choi, J. H., Han, D. J., Kim, H. Y., Lee, M. A., Jeong, J. Y., Chung, H. J., and Kim, C. J. (2010b) Effects of replacing pork back fat with vegetable oils and rice bran fiber on the quality of reduced-fat frankfurters. Meat Sci. 84, 557563.

12. Choi, Y. S., Choi, J. H., Han, D. J., Kim, H. Y., Lee, M. A., Kim, H. W., and Kim, C. J. (2009) Characteristics of low-fat meat emulsion systems with pork fat replaced by vegetable oils and rice bran fiber. Meat Sci. 82, 266-271.

13. Choi, Y. S., Choi, J. H., Han, D. J., Kim, H. Y., Lee, M. A., Kim, H. W., Jeong, J. Y., and Kim, C. J. (2011) Effects of rice bran fiber on heat-induced gel prepared with pork salt-soluble meat proteins in model system. Meat Sci. 88, 59-66.

14. Choi, Y. S., Choi, J. H., Han, D. J., Kim, H. Y., Lee, M. A., Lee, E. S., Jeong, J. Y., Paik, H. D., and Kim, C. J. (2008) Effects of rice bran fiber on quality of low-fat tteokgalbi. Food Sci. Biotechnol. 17, 959-964.

15. Choi, Y. S., Park, K. S., Choi, J. H., Kim, H. W., Song, D. H., Kim, J. M., Chung, H. J., and Kim, C. J. (2010a) Physicochemical properties of chicken meat emulsion systems with dietary fiber extracted from makgeolli lees. Korean J. Food Sci. Anim. Resour. 30, 910-917.

16. Chung, H. J. (2009) Influence of purple sweet potato powder addition on the quality characteristics and oxidative stability of cookies. J. Food Sci. Nutr. 14, 60-65.

17. Colmenero, F. J., Ayo, M. J., and Carballo, J. (2005) Physicochemical properties of low sodium frankfurter with added walnut: Effect of transglutaminase combined with caseinate, $\mathrm{KCl}$ and dietary fibre as salt replacers. Meat Sci. 69, 781788.

18. Desmond, E. M., Troy, D. J., and Buckley, D. J. (1998) The effects of tapioca starch, oat fiber and whey protein on the 
physical and sensory properties of low-fat beef burgers. $L W T$ - Food Sci. Technol. 31, 653-657.

19. Deumier, F. and Collignan, A. (2003) The effects of sodium lactate and starter cultures on $\mathrm{pH}$, lactic acid bacteria, Listeria monocytogenes and Salmonella spp. levels in pure chicken dry fermented sausage. Meat Sci. 65, 1165-1174.

20. Eim, V. S., Simal, S., Rosselló, C., and Femenia, A. (2008) Effects of addition of carrot dietary fibre on the ripening process of a dry fermented sausage (sobrassada). Meat Sci. 80, 173-182.

21. Fernández-Ginés, J. M., Fernandez-López, J., Sayas-Barberá, E., Sendra, E., and Pérez-Álvarez, J. A. (2004) Lemon albedo as a new source of dietary fiber: Application to bologna sausages. Meat Sci. 67, 7-13.

22. Garcia, M. L., Dominguez, R., Galvez, M. D., Casas, C., and Selgas, M. D. (2002) Utilization of cereal and fruit fibers in low fat dry fermented sausages. Meat Sci. 60, 227-236.

23. Grigelmo-Miguel, N., Abadias-Seros, M. I., and Martin-Belloso, O. (1999) Characterization of low-fat high dietary fibre frankfurters. Meat Sci. 52, 247-256.

24. Hwang, K. E., Choi, Y. S., Choi, J. H., Kim, H. Y., Kim, H. W., Lee, M. A., Chung, H. K., and Kim, C. J. (2011) Effect of ganghwayakssuk (Artemisia princeps Pamp.) on oxidative stability of deep fried chicken nuggets. Food Sci. Biotechnol. 20, 1381-1388.

25. Jeong, J. W. and Park, K. J. (2006) Quality characteristics of loaf bread added takju powder. Korean J. Food Sci. Technol. 38, 52-58.

26. Jeong, J. W., Park, K. J., Kim, M. H., and Kim, D. S. (2006) Changes in quality of spray-dried and freeze-dried takju powder during storage. Korean J. Food Sci. Technol. 38, 513-520.

27. Kim, E. J., Kim, D. K., Lee, D. S., Lee, T. S., and Noh, B. S. (1995) Application of acid urease to prevent ethyl carbamate formation in takju processing. Food Biotechnol. 4, 34-38.

28. Kim, S. M. and Cho, W. K. (2006) Effects of takju (Korean turbid rice wine) lees on the serum glucose levels in streptozotocin-induced diabetic rats. Korean J. Food Culture 21, 638-643.

29. Lee, H. S., Hong, K. H., Kim, J. Y., Kim, D. H., Yoon, C. H., and Kim, S. M. (2009) Blood pressure lowering effect of Korean turbid rice wine (takju) lees extracts in spontane- ously hypertensive rat (SHR). Korean J. Food Culture 24, 338-343.

30. Lee, J. S., Lee, T. S., Noh, B. S., and Park, S. O. (1996) Quality characteristics of mash of takju prepared by different raw materials. Korean J. Food Sci. Technol. 28, 330-336.

31. Lee, M. A., Han, D. J., Jeong, J. Y., Choi, J. H., Choi, Y. S., Kim, H. Y., Paik, H. D., and Kim, C. J. (2008) Effect of kimchi powder level and drying methods on quality characteristics of breakfast sausage. Meat Sci. 80, 708-714.

32. Mansour, E. H. and Khalil, A. H. (1999) Characteristics of low-fat beef burgers as influenced by various types of wheat fibers. J. Sci. Food Agric. 79, 493-498.

33. Park, C. S. and Lee, T. S. (2002) Quality characteristics of takju prepared by wheat flour nuruks. Korean J. Food Sci. Technol. 34, 296-302.

34. Sánchez-Zapata, E., Muñoz, C. M., Fuentes, E., FernándezLópez, J., Sendra, E., Sayas, E., Navarro, C., and PérezAlvarez, J. A. (2010) Effect of tiger nut fibre on quality characteristics of pork burger. Meat Sci. 85, 70-76.

35. SAS. (2008) SAS/STAT Software for PC. Release 9.2, SAS Institute Inc., Cary, NC, USA.

36. Steenblock, R. L., Seeranek, J. G., Olson, D. G., and Love, J. A. (2001) The effects of oat fiber on the properties of light bologna and fat-free frankfurters. J. Food Sci. 66, 14091415.

37. Thebaudin, J. Y., Lefebvre, A. C., Harrington, M., and Bourgeois, C. M. (1997) Dietary fibers: nutitional and technological interest. Trends Food Sci. Technol. 8, 41-48.

38. Turhan, S., Sagir, I., and Ustun, N. S. (2005) Utilization of hazelnut pellicle in low-fat beef burgers. Meat Sci. 71, 312316.

39. Won, J. H., Son, J. A., Youn, A. R., Kim, H. J., Kim, G. W., and Noh, B. S. (2006) Quality characteristics of pork with addition of jubak (sulchigegie). Korean J. Food Culture 21, 565-570.

40. Xiong, Y. L., Noel, D. C., and Moody, W.G. (1999) Textural and sensory properties of low-fat beef sausages with added water and polysaccharides as affected by $\mathrm{pH}$ and salt. $J$. Food Sci. 64, 550-554.

(Received 2011.9.20/Revised 2012.2.5/Accepted 2012.2.6) 